\title{
Ecological and Physiological Controls of Species Composition in Green Macroalgal Blooms
}

\author{
Kathryn L. Van Alstyne Dr. \\ Western Washington University, kathy.vanalstyne@wwu.edu
}

Timothy A. Nelson

Karalon Haberlin

Amorah V. Nelson

Heather Ribarich

See next page for additional authors

Follow this and additional works at: https://cedar.wwu.edu/shannonpoint_facpubs

Part of the Marine Biology Commons

\section{Recommended Citation}

Van Alstyne, Kathryn L. Dr.; Nelson, Timothy A.; Haberlin, Karalon; Nelson, Amorah V.; Ribarich, Heather; Hotchkiss, Ruth; Buckingham, Lee; Simunds, Dejah J.; and Fredrickson, Kerri, "Ecological and Physiological Controls of Species Composition in Green Macroalgal Blooms" (2008). Shannon Point Marine Center Faculty Publications. 2.

https://cedar.wwu.edu/shannonpoint_facpubs/2 
Authors

Kathryn L. Van Alstyne Dr., Timothy A. Nelson, Karalon Haberlin, Amorah V. Nelson, Heather Ribarich, Ruth Hotchkiss, Lee Buckingham, Dejah J. Simunds, and Kerri Fredrickson 


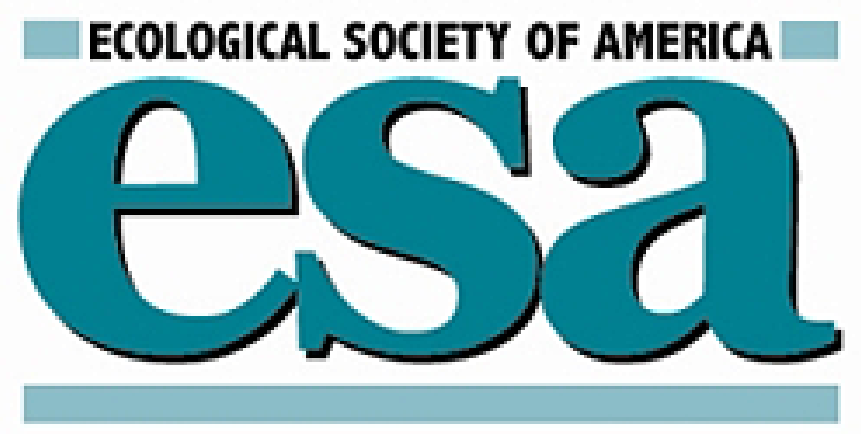

Ecological and Physiological Controls of Species Composition in Green Macroalgal Blooms Author(s): Timothy A. Nelson, Karalon Haberlin, Amorah V. Nelson, Heather Ribarich, Ruth Hotchkiss, Kathryn L. Van Alstyne, Lee Buckingham, Dejah J. Simunds and Kerri Fredrickson Source: Ecology, Vol. 89, No. 5 (May, 2008), pp. 1287-1298

Published by: Ecological Society of America

Stable URL: http://www.jstor.org/stable/27651674

Accessed: 17/10/2014 10:49

Your use of the JSTOR archive indicates your acceptance of the Terms \& Conditions of Use, available at http://www.jstor.org/page/info/about/policies/terms.jsp

JSTOR is a not-for-profit service that helps scholars, researchers, and students discover, use, and build upon a wide range of content in a trusted digital archive. We use information technology and tools to increase productivity and facilitate new forms of scholarship. For more information about JSTOR, please contact support@jstor.org. 


\title{
ECOLOGICAL AND PHYSIOLOGICAL CONTROLS OF SPECIES COMPOSITION IN GREEN MACROALGAL BLOOMS
}

\author{
Timothy A. Nelson, ${ }^{1,3}$ Karalon Haberlin, ${ }^{1}$ Amorah V. Nelson, ${ }^{1}$ Heather Ribarich, ${ }^{1}$ Ruth Hotchiss, ${ }^{1}$ \\ Kathryn L. Van Alstyne, ${ }^{2}$ Lee Buckingham, ${ }^{1}$ Dejah J. Simunds, ${ }^{1}$ and Kerri Fredrickson ${ }^{2}$ \\ ${ }^{1}$ Blakely Island Field Station, Suite 205, Seattle Pacific University, Seattle, Washington 98119-1950 USA \\ ${ }^{2}$ Shannon Point Marine Center, Western Washington University, 1900 Shannon Point Road, Anacortes, Washington 98221 USA
}

Abstract. Green macroalgal blooms have substantially altered marine community structure and function, specifically by smothering seagrasses and other primary producers that are critical to commercial fisheries and by creating anoxic conditions in enclosed embayments. Bottom-up factors are viewed as the primary drivers of these blooms, but increasing attention has been paid to biotic controls of species composition. In Washington State, USA, blooms are often dominated by Ulva spp. intertidally and Ulvaria obscura subtidally. Factors that could cause this spatial difference were examined, including competition, grazer preferences, salinity, photoacclimation, nutrient requirements, and responses to nutrient enrichment. Ulva specimens grew faster than Ulvaria in intertidal chambers but not significantly faster in subtidal chambers. Ulva was better able to acclimate to a high-light environment and was more tolerant of low salinity than Ulvaria. Ulvaria had higher tissue $\mathrm{N}$ content, chlorophyll, chlorophyll $b$ : chlorophyll $a$, and protein content than Ulva. These differences suggest that nitrogen availability could affect species composition. A suite of five grazers preferred Ulva to Ulvaria in choice experiments. Thus, bottom-up factors allow Ulva to dominate the intertidal zone while resistance to grazers appears to allow Ulvaria to dominate the subtidal zone. While ulvoid algae are in the same functional-form group, they are not functionally redundant.

Key words: ecological redundancy; functional form; grazing; green tides; light; macroalgal blooms, nitrogen; plant-herbivore interactions; salinity; Ulva; Ulvaria; Washington, USA.

\section{INTRODUCTION}

Macroalgal blooms have been blamed for eradicating seagrass meadows, altering faunal community structure, and creating unsightly, malodorous piles on beaches (e.g., Valiela et al. 1997; see Plate 1). These effects are usually associated with shading and anoxia, although extracts from some bloom-forming macroalgae have been shown to be toxic (Nelson et al. 2003a; see Plate 1). Blooms are often associated with eutrophication, although a variety of abiotic and biotic factors may limit ulvoid algal abundance and productivity (Kida 1990, Henley et al. 1991, Rivers and Peckol 1995, Anderson et al. 1996). Problematic blooms are typically reported to be monospecific (Valiela et al. 1997), with the dominant species determined by environmental conditions (Lotze et al. 2000). In Washington State, USA, Ulva lactuca $\mathrm{L}$. often dominates the intertidal zone and Ulvaria obscura (Kützing) Gayral dominates the subtidal bloom (Nelson et al. 2003b). Blooms substantial enough to inhibit eelgrass (Zostera marina L.) growth occur at several sites (Nelson and Lee 2001; see Plate 1).

Manuscript received 22 March 2007; revised 14 September 2007; accepted 21 September 2007. Corresponding Editor (ad hoc): C. S. Thornber.

${ }^{3}$ E-mail: tnelson@spu.edu
Community structure in marine environments has been examined more thoroughly in rocky intertidal areas than on the soft substrata where macroalgal blooms typically occur. In the first half of the 20th century, zonation was assumed to be controlled by physical factors. Subsequent experimentation demonstrated the roles of predation, competition, and refuges (Robles and Desharnais 2002). Soft-substratum marine macroalgal communities have not been so thoroughly examined and studies of bottom-up processes, particularly eutrophication, have predominated. Research has focused on shifts from seagrass-dominated communities to macroalgal or phytoplankton domination with increasing eutrophication (Taylor et al. 1995, Valiela et al. 1997). While nutrients are most associated with changes in biomass, light can be the limiting factor for ulvoid growth at low irradiance or at high seawater $\mathrm{N}$ concentration (Coutinho and Zingmark 1993). Salinity (Josselyn 1985), temperature (Rivers and Peckol 1995), bloom-induced anoxia (Sfriso et al. 1987), and grazing (Geertz-Hansen et al. 1993) also play roles in controlling abundance. However, "green tide" algae are generally reported to have broad tolerance ranges for salinity, irradiance, and temperature (Taylor et al. 2001).

While these various physical and biological factors have been used to explain changes in macroalgal biomass, they have rarely been used to explain 
differences in species composition. The functional form hypothesis suggests that similar species are ecologically equivalent and that thin-bladed species are expected to grow faster and be preferred by grazers than thickbladed or crustose forms (Littler and Littler 1980). The location and extent of green tides (i.e., ulvoid algal blooms) may be predictable as a functional-form group, but understanding the causes of species-specific distribution patterns is more difficult (Steneck and Dethier 1994).

Only a few studies have determined the causes of spatial or temporal changes in the species composition of macroalgal blooms. Lotze and colleagues elegantly demonstrated the importance of recruitment timing, herbivory, and nutrient supply on competition between ephemeral blooms of Ulva spp. (reported as Enteromorpha spp.) and the brown alga Pilayella littoralis (Lotze et al. 1999, Lotze and Schramm 2000). Fong et al. (1996) showed that salinity and nitrogen could explain dominance patterns in Ulva expansa and $U$. intestinalis (reported as Enteromorpha intestinalis). Still, relatively little attention has focused on the effects of predation or competition between macroalgal species on community structure.

In the present study we examine the environmental factors that allow Ulva lactuca (hereafter Ulva) to dominate the intertidal zone and Ulvaria obscura (hereafter Ulvaria) to dominate the subtidal zone in Washington State, USA (Nelson et al. 2003b). As has been the case in studies of rocky intertidal zonation (Robles and Desharnais 2002), we began by looking for differences in physical parameters that allowed Ulvaria to succeed in the subtidal zone while Ulva thrived intertidally. We then examined biotic interactions, specifically competition and herbivory.

We grew algae in the subtidal and intertidal zones in Plexiglas chambers, alone or with the other species, and measured growth rates to determine which species would grow faster with limited biotic interactions. Given the elevation pattern typically seen with these species, our hypothesis was that Ulva would grow faster in the intertidal zone and Ulvaria in the subtidal zone (hypothesis 1). Specific differences in respiration and photosynthetic rates in response to acclimation to various light environments might help explain the elevational difference we note, since there is less light available in the subtidal zone. Typically, shade-tolerant algae are expected to have a reduced light-saturated rate of photosynthesis and, when grown at low light, lower respiration rate and faster photosynthetic response to increasing light (Lobban and Harrison 1994). We expected that the shallower-growing Ulva would display adaptation to high light intensity, while Ulvaria would be adapted to lower light conditions (hypothesis 2). To examine this, the two species were grown at fixed depths and in fixed light environments and their photosynthetic and respiration responses were measured. Responses to salinity were examined, since the intertidal zone is occasionally inundated with freshwater following rainfall. Since Ulva is more common in the intertidal zone, we expected that it might be more resistant to low salinity (hypothesis 3 ). Since $\mathrm{N}$ often appears to be a limiting factor in ulvoid blooms, we varied seawater nitrogen concentration and measured growth rate and key internal $\mathrm{N}$ pools (i.e., protein content, chlorophyll $a$ and $b$, and total tissue $\mathrm{N}$ and $\mathrm{C}$ ). Nitrogen acquisition may be particularly problematic for intertidal species, since there is limited time for uptake (Phillips and Hurd 2004), thus differences in nitrogen use patterns might be expected (hypothesis 4). For example, high intertidal species might store nitrogen during periods of abundance (Phillips and Hurd 2003), but be more vulnerable to growth limitation during periods of low nitrogen availability. Further, if Ulvaria is shade-adapted, we expected that it would have greater total pigment content and chlorophyll $b: a$ ratios than Ulva (hypothesis 2; Ramus et al. 1976, Henley and Ramus 1989).

Lastly, we compared grazer preferences for the two species. Most marine grazers are active only when covered by water; thus grazing tends to be most intense in the subtidal zone. An exception that ultimately follows the rule of reduced intertidal grazing is Littorina sitkana, which only feeds at low tide. Further, in the soft-substratum areas where local green tides occur, mid-intertidal grazers are virtually absent, while Lacuna spp. and Strongylocentrotus droebachiensis are often abundant in the low intertidal zone and subtidal zone (T. A. Nelson, personal observation; K. L. Van Alstyne, unpublished data). If grazers control species distribution, then Ulvaria should be less preferred by grazers than Ulva, giving it an advantage in the subtidal zone (hypothesis 5).

\section{Methods \\ Species and site descriptions}

Green tides present an interesting challenge to marine ecologists. Multiple species may be found growing together in the intertidal or subtidal zones, either attached to the substratum or floating freely. The greatest biomass found locally occurs in free-floating mats that remain stationary in embayments. The genera involved (Ulva and Ulvaria in Washington State, USA) are superficially similar green blades and cannot be accurately distinguished in the field. During blooms both genera and multiple Ulva spp. may be present (Nelson et al. 2003b). Collection and field sites were located within the San Juan Island Archipelago, Washington State, USA, or in the vicinity of Seattle, Washington, USA. Sites are described fully in Nelson et al. $(2003 b)$ or in Appendix A, Table A1.

\section{Growth at different depths (hypothesis 1)}

We hypothesized that Ulvaria would grow faster than Ulva in the subtidal zone (and the reverse in the intertidal zone) in the absence of predators or other macroalgal species. We measured growth of Ulva and Ulvaria at 0 
and $-2 \mathrm{~m}$ MLLW in the absence of interspecific interactions by growing each species in chambers anchored to the substratum for $14 \mathrm{~d}$ (23 July to 10 August 1998). Chambers consisted of $0.64 \mathrm{~cm}$ thick, 20 $\mathrm{cm}$ diameter Plexiglas tubing cut down the long axis, forming half-cylinders $20 \mathrm{~cm}$ long. Plastic window screening was attached to the bottom and two ends of the half-cylinder with silicone sealant. The screening material and holes drilled into the Plexiglas to attach anchoring ropes allowed for substantial water exchange through the chamber. Six replicate microcosms containing four $9.4 \mathrm{~cm}$ diameter disks cut from algal thalli $(\sim 2.5$ $\mathrm{g}$ fresh algal biomass per chamber) were used for each depth $\times$ species combination. The area of the algal disks was measured before and after incubation using a LI3000A area meter (LI-COR, Lincoln, Nebraska, USA). A two-way ANOVA was used to analyze the data, with depth and species treated as fixed factors. Data were averaged for each chamber, and chambers were treated as individual replicates. Tukey's post hoc test was used for multiple comparisons. Data for all experiments described here were analyzed using SPSS 13.0 (SPSS, Chicago, Illinois, USA). Assumptions of normality and homoscedasticity were verified for this experiment and all others that follow. Unless specifically noted, the data did not depart significantly from these assumptions.

To determine whether competitive interactions favored Ulvaria in the subtidal zone, we grew disks of Ulva and Ulvaria together in chambers at -1 and $-2 \mathrm{~m}$ MLLW. Eight disks of each species $(\sim 10 \mathrm{~g}$ total algal fresh biomass) were placed in a chamber. Twenty chambers were placed at each depth on 21 July 1999 and retrieved on 5 August 1999. A blocked ANOVA was used for analysis, with species and depths treated as fixed factors and chambers treated as blocks within depths. In both of the preceding experiments, several chambers lost one of the specimens over the course of the experiment. We suspect SCUBA divers damaged the seal between screening material and Plexiglas during removal from the field, allowing a thallus to escape the chamber.

\section{Light acclimation (hypothesis 2)}

We hypothesized that Ulva would have a higher lightsaturated rate of photosynthesis, a higher rate of dark respiration, and a slower photosynthetic response to increasing light when light is limited than Ulvaria because it is more often found in the intertidal zone. Ulva and Ulvaria were grown at different depths and photosynthetic responses were measured to determine whether adaptation to light intensity could account for their vertical distribution. Each replicate consisted of one $10 \mathrm{~cm}$ diameter algal disk placed in an uncapped $\sim 600$-mL clear polyethylene bottle with holes cut to allow water flow. The shape of the bottles (having a narrower neck than body) caused them to orient with the mouth pointed into the current or upward in the absence of current, preventing the loss of algal tissue from the bottle. Bottles were suspended at $2.5-\mathrm{m}$ depth increments from the surface to $7.5 \mathrm{~m}$ deep. Five replicate bottles of each species were suspended at each depth. The bottles were strung from a single anchored line attached to surface buoys and deployed haphazardly $\sim 200 \mathrm{~m}$ north of Seal Pup Rock, Blakely Island. This apparatus was left in place for $12 \mathrm{~d}$. Four disks $2.4 \mathrm{~cm}$ in diameter were then cut from each of the replicate specimens and placed in a biological oxygen demand (BOD) bottle, where photosynthesis was measured over a 60-min incubation period using an $\mathrm{O}_{2}$ electrode (YSI 59 meter and 5905 probe; Yellow Springs Instruments, Yellow Springs, Ohio, USA). Photosynthesis was measured under 500-W halogen lamps (model L-33; The Designer's Edge, Bellevue, Washington, USA) at five increasingly higher light intensities $(0, \sim 10, \sim 50$, $\sim 100$, and $\sim 200 \mu \mathrm{mol}$ photons $\cdot \mathrm{m}^{-2} \cdot \mathrm{s}^{-1}$, with precise intensity measured for each replicate). This corresponds to the full range of light intensities likely experienced by specimens grown at a fixed depth of $-7.5 \mathrm{~m}$. Surfacegrown plants experience light intensities as high as 1800 $\mu \mathrm{mol}$ photons $\cdot \mathrm{m}^{-2} \cdot \mathrm{s}^{-1}$ (Nelson and Waaland 1997). Photosynthetic rate was regressed against light intensity using the following relationship (Peterson et al. 1987):

$$
p_{\mathrm{n}}=p_{\text {nmax }}-p_{\text {gmax }} e^{-\beta I}
$$

where $p_{\mathrm{n}}$ is the measured net rate of photosynthesis, $p_{\text {nmax }}$ is the net light-saturated rate of photosynthesis, $p_{\text {gmax }}$ is the gross light-saturated rate of photosynthesis, $\beta$ is a derived parameter that is proportional to the slope of the curve at low light intensities ( $\beta p_{\text {gmax }}$ approaches $\alpha$ at low light intensity, where $\alpha$ is the initial slope), and $I$ is measured irradiance. We used nonlinear regression to determine $p_{\text {nmax }}, p_{\text {gmax }}$, and $\beta$. Multiple comparisons of $p_{\text {nmax }}$ and $\beta$ across species $\times$ depth combinations were made using a Tukey test following Zar (1999).

Because acclimation to low light intensity often involves reduced respiration, we examined differences in respiration rate among algae acclimated to different light environments. We expected that Ulvaria would have lower rates of dark respiration if it were shadeadapted. Algae were acclimated for $7 \mathrm{~d}$ at zero, low, and high light intensities. Algae for the zero and low-light $\left(0.50-6.49 \mu \mathrm{mol}\right.$ photons $\left.\cdot \mathrm{m}^{-2} \cdot \mathrm{s}^{-1}\right)$ treatments were placed in indoor seawater tables. For zero light, a tent of opaque plastic sheeting was placed over the table. The high-light $\left(0.56-1506 \mu \mathrm{mol}\right.$ photons $\left.\cdot \mathrm{m}^{-2} \cdot \mathrm{s}^{-1}\right)$ seawater table was outdoors. Respiration rate was measured as $\mathrm{O}_{2}$ loss in a dark bottle at ambient seawater temperature over $24 \mathrm{~h}$ following the acclimation period. Five replicate BOD bottles were used for each species $\times$ light acclimation combination. Data were analyzed using a two-factor ANOVA with light treatment and species treated as fixed factors.

\section{Salinity (hypothesis 3)}

We hypothesized that Ulva would be more tolerant of low salinity than Ulvaria since intertidal salinity is more 
influenced by rainfall than subtidal salinity. The impact of salinity was determined by growing $6.2 \mathrm{~cm}$ diameter disks of Ulva and Ulvaria at salinities of 5, 10,20, and 30 PSU. Disks were placed individually in $500-\mathrm{mL}$ cylindrical culture vessels containing $300 \mathrm{~mL}$ filtered, sterilized seawater (or diluted seawater) supplemented with Guillard's f/2 (Sigma-Aldrich, St. Louis, Missouri, USA). The medium was changed daily. Each species $X$ salinity treatment was replicated four (Ulva at 10 PSU) or five times (all others). The algae were incubated for 10 $\mathrm{d}$ in a growth chamber at $12^{\circ} \mathrm{C}$ with a $14: 10 \mathrm{~L}: \mathrm{D}$ photoperiod $\left(\sim 150 \mu \mathrm{mol}\right.$ photons $\left.\cdot \mathrm{m}^{-2} \cdot \mathrm{s}^{-1}\right)$. The area of each disk was measured before and after the incubation period. Growth data were rank-transformed to eliminate significant skew and kurtosis and analyzed using a twofactor ANOVA with salinity and species treated as fixed factors.

\section{Nitrogen (hypotheses 2 and 4)}

Given potential differences in $\mathrm{N}$ availability in the subtidal and intertidal zones, we hypothesized that Ulva and Ulvaria might maintain different tissue $\mathrm{N}$ content and might differentially allocate $\mathrm{N}$ to pigments based on the difference in light environment they usually experience. Field measurements were used to compare tissue $\mathrm{N}$ in Ulva and Ulvaria. Algae were collected on 6 July 2004 from Armitage Bay and the West Beach of Blakely Island. The former site typically has relatively higher seawater $\mathrm{N}$ concentration than the latter (Nelson et al. $2003 b$ ). Nitrogen and $C$ content were determined in six replicates per site $X$ species combination. One of the Ulvaria replicates from Armitage Bay was contaminated during analysis and these data were discarded. Differences in tissue $\mathrm{N}, \mathrm{C}$, and $\mathrm{C}: \mathrm{N}$ were analyzed using MANOVA with sites and species treated as fixed factors.

Ulva and Ulvaria were also grown at ambient and elevated seawater $\mathrm{N}$ concentrations; growth and tissue $\mathrm{N}$ concentration, $\mathrm{C}$ concentration, and $\mathrm{C}: \mathrm{N}$ were measured. Eight $4.36 \mathrm{~cm}^{2}(\sim 0.31 \mathrm{~g}$ fresh mass) disks of each species were placed in individual culture vessels (described in Salinity (hypothesis 3)) with either seawater (control, low $\mathrm{N}$ ), seawater $+20 \mu \mathrm{mol} / \mathrm{L} \mathrm{NH}_{4} \mathrm{NO}_{3}$ (medium $\mathrm{N}$ ), or seawater $+80 \mu \mathrm{mol} / \mathrm{L} \mathrm{NH}_{4} \mathrm{NO}_{3}$ (high $\mathrm{N}$ ). The algae were cultured for $10 \mathrm{~d}$ at $12^{\circ} \mathrm{C}$ in a growth chamber set to a 14:10 L:D photoperiod $\left(\sim 150 \mu \mathrm{mol}\right.$ photons $\left.\cdot \mathrm{m}^{-2} \cdot \mathrm{s}^{-1}\right)$. The media were changed daily to refresh nutrient supplies. The data were analyzed using MANOVA with species treated as a fixed factor. Tukey's hsd post hoc test was used in cases in which significant effects of $\mathrm{N}$ concentration were noted.

In a second similar experiment, we measured tissue chlorophyll $a$ (chl $a$ ), chlorophyll $b(\mathrm{chl} b$ ), chlorophyll $b: a$ (chl $b: a)$, and tissue [protein] of algal tissues following acclimation to low and medium $\mathrm{N}$ concentrations. We hypothesized that Ulvaria would have higher pigment content and chl $b: a$ than Ulva if it were adapted to lower light conditions. Five replicate disks of each species were placed in the nutrient media and incubated in a cold room at $12^{\circ} \mathrm{C}$ with a $14: 10 \mathrm{~L}: \mathrm{D}$ photoperiod $\left(\sim 80 \mu \mathrm{mol}\right.$ photons $\left.\cdot \mathrm{m}^{-2} \cdot \mathrm{s}^{-1}\right)$ for $10 \mathrm{~d}$. Thallus [protein] was determined in $\sim 3 \mathrm{~cm}$ diameter disks using the farUV technique (Aitken and Learmonth 1996). Protein content was converted to units of dry mass (dm) by assuming a dry mass : fresh mass ratio of $0.166: 1.0$ based on prior observations (Nelson et al. 2003b). Chlorophyll $a$ and $b$ contents were determined by acetone extraction from $\sim 2.4 \mathrm{~cm}$ diameter disks of algal tissue (Lobban et al. 1988). Total tissue $\mathrm{C}$ and $\mathrm{N}$ were determined with a CE Elantech 1112 elemental analyzer (CE Elantech, Oberlin, New Jersey, USA) using atropine as a standard.

\section{Grazing experiments (hypothesis 5)}

We hypothesized that Ulvaria would be more resistant to grazing than Ulva since grazers are more abundant in the subtidal zone in local areas where green tides occur. Five species of grazers (the snails Littorina sitkana, Lacuna variegata, and Lacuna vincta, the isopod Idotea wosnesenskii, and the urchin Strongylocentrotus droebachiensis) were given the choice of Ulva or Ulvaria in laboratory studies. These grazers were chosen because they are abundant in the vicinity of local blooms Grazers were placed in an arena with a $9.5 \mathrm{~cm}$ diameter disk of Ulva and the same size disk of Ulvaria. Grazers were starved for $24-48 \mathrm{~h}$ prior to the start of the experiment. The algal disks' surface areas were measured before and after exposure to grazers. To eliminate other possible explanations for tissue loss (e.g., sporulation or gametogenesis), grazer-free controls were grown simultaneously. The grazers and algal disks were incubated in 24-h darkness to equalize algal growth rate between the two species at nearly zero. Reduced light may impact algal palatability and the presence of secondary metabolites in some species, but does not appear to affect either in other species (Cronin and Hay 1996). Where known, light does not affect the concentration of grazer deterrents in the species considered in this study (Van Alstyne et al. 2007). Further, controls appeared healthy and structurally sound following the dark incubation period. The data were analyzed using a paired-sample $t$ test of the change in size of each algal species within a replicate arena. Due to significant departures from normality in the isopod feeding test, the Wilcoxon signed-ranks test was performed on these data. Arena construction and incubation details are provided in Appendix A, Table A3.

To determine whether grazers would eat substantial quantities of the less-preferred alga, we fed L. vincta only Ulva or only Ulvaria. The snails were presented with two conspecific algal disks instead of one of each species. The data were analyzed with a two-sample $t$ test comparing grazing on only Ulva with grazing on only Ulvaria. We used the snails from this experiment to see whether acclimation to one food source altered the preference of the snails in a subsequent food choice experiment. Thus, the snails that had been fed only 


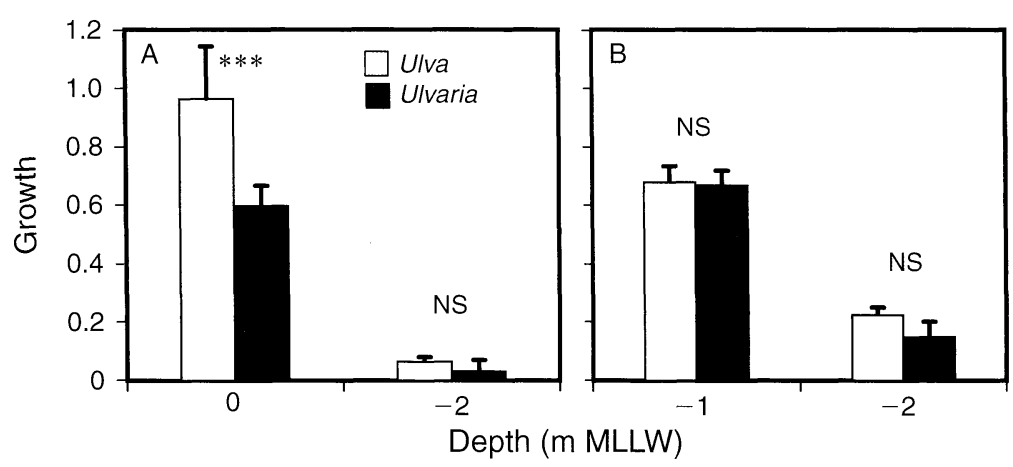

FIG. 1. Growth (proportional change in surface area; mean + SE) of Ulva and Ulvaria in microcosms at different depths: (A) results when grown in monospecific chambers; (B) results when both species are grown together. Collection and field sites were located within the San Juan Island Archipelago, Washington State, USA, or in the vicinity of Seattle, Washington, USA.

*** $P<0.001 ;$ NS, no significant difference between species $(P>0.05)$.

Ulvaria or only Ulva for $7 \mathrm{~d}$ were subsequently given the choice of both species for $7 \mathrm{~d}$. These data were analyzed by performing a two-sample $t$ test on the difference between the quantity of Ulva and Ulvaria consumed by snails pre-fed Ulva and those pre-fed Ulvaria. This is a simple extension of the paired-sample $t$ test with the $H_{0}$ that the difference between Ulva and Ulvaria consumption is the same regardless of prior experience.

\section{Beach and tide pool comparison}

Based on the results of experiments described previously, we predicted that Ulva would grow faster (or disappear more slowly) on air-exposed intertidal rocks and Ulvaria would grow better in heavily grazed tide pools. On the exposed rocks, the faster-growing Ulva should dominate. In the tide pool, the more grazerresistant Ulvaria should thrive. We identified "heavily grazed tide pools" as those dominated by crustose coralline algae and limpets and notably lacking fleshy algal cover as compared to surrounding benches. In a series of three experiments, we placed specimens of Ulva and Ulvaria in heavily grazed tide pools and in the intertidal zone. In each, we used clothespins to attach 10-159 cm diameter disks cut from algal thalli on lines anchored to the substratum for $10 \mathrm{~d}$. The areas of the algal thalli were measured before and after this treatment. We placed lines in tide pools near Pinnacle Rock, Blakely Island, and at Cattle Point, San Juan Island, on 20 June and 4 August 2001, respectively. We also placed lines in the rocky intertidal zone near Pinnacle Rock on 30 June 2002. For each experiment, a one-sided $t$ test was used to compare the mean change in size of Ulva vs. Ulvaria. For the two tide pool experiments, heteroscedasticity required us to use Welch's $t$ test (Zar 1999).

Results

\section{Growth at different depths}

We predicted that Ulvaria would grow faster than Ulva in the subtidal zone, while Ulva would grow faster in the intertidal zone (hypothesis 1). In single-species chambers, Ulva grew $29 \%$ more than Ulvaria at $0 \mathrm{~m}(P$ $<0.001)$, but not significantly more at $-2.0 \mathrm{~m}(P=$ 0.977). Ulva and Ulvaria grew $68 \%$ and $42 \%$ more, respectively, in chambers at $0 \mathrm{~m}$ than at $-2 \mathrm{~m}(P<0.001$ for both comparisons; Fig. 1 and Appendix B, Tables B1.1 and B1.2). When Ulva and Ulvaria were grown together, they grew $36 \%$ faster at -1 than at $-2 \mathrm{~m}(P<$ $0.001)$. Neither species grew significantly faster than the other $(P=0.208)$ when grown together.

\section{Light acclimation}

The vertical difference in species distribution could also be caused by variance in adaptation to light environment (hypothesis 2). Ulva acclimated to light conditions by increasing $p_{\text {nmax }}$ when grown in shallower water, while Ulvaria maintained relatively low $p_{\text {nmax }}$ regardless of acclimation depth (Table 1, Appendix B, section 2, and Appendix C). Ulva grown at $0 \mathrm{~m}$ had $p_{\text {nmax }} 26 \%$ higher than specimens grown at -5 and -7.5 $\mathrm{m}(0.005>P>0.001$ for both). Ulva grown at $-2.5 \mathrm{~m}$ had a $p_{\text {nmax }}$ intermediate between the shallower- and deeper-grown specimens but was not significantly different from either. The $p_{\text {nmax }}$ for Ulvaria did not vary significantly with the depth at which it was grown ( $P>0.10$ for all comparisons). Ulva always had a 13$54 \%$ higher $p_{\text {nmax }}$ than Ulvaria when grown at the same depth, although the difference was only significant in specimens grown at $0(0.005>P>0.001)$ and $-7.5 \mathrm{~m}$ $(0.005>P>0.001)$. High variance (and resultant low statistical power) associated with $\beta$ values prevented us from detecting any significant differences between species or among depths. However, as might be expected, the $\beta$ value for Ulva increased consistently with depth and was $46 \%$ higher at $-7.5 \mathrm{~m}$ than at $0 \mathrm{~m}$ (Table 1). Ulvaria generally had higher $\beta$ values than Ulva, but they did not change consistently with increasing depth.

Respiration rates of specimens grown in high light were 2.56 times greater than specimens acclimated to low or no light $(P<0.001$; Fig. 2 and Appendix B, 
TABLE 1. Parameter values (means $\pm \mathrm{SE}$ ) from best-fit nonlinear regression of light intensity vs. net photosynthetic rate for $U l v a$ and Ulvaria acclimated to different depths.

\begin{tabular}{lcccc}
\hline \hline & \multicolumn{3}{c}{ Acclimation depth $(\mathrm{m})$} \\
\cline { 2 - 5 } \multicolumn{1}{c}{ Parameter } & 0 & 2.5 & 5 & 7.5 \\
\hline$p_{\text {nmax }}$ Ulva $\left(\mathrm{mg} \mathrm{O}_{2} / \mathrm{h}\right)$ & $0.433 \pm 0.0258$ & $0.375 \pm 0.0241$ & $0.335 \pm 0.0205$ & $0.352 \pm 0.0175$ \\
$p_{\text {nmax }}$ Ulvaria $\left(\mathrm{mg} \mathrm{O}_{2} / \mathrm{h}\right)$ & $0.281 \pm 0.0359$ & $0.329 \pm 0.0142$ & $0.280 \pm 0.0210$ & $0.274 \pm 0.0157$ \\
$\beta$ Ulva $\left(\left[\mu \mathrm{mol} \mathrm{photons} \cdot \mathrm{m}^{-2} \cdot \mathrm{s}^{-1}\right]^{-1}\right)$ & $0.0209 \pm 0.00370$ & $0.0287 \pm 0.00665$ & $0.0300 \pm 0.00661$ & $0.0306 \pm 0.00562$ \\
$\beta$ Ulvaria $\left(\left[\mu \mathrm{mol} \mathrm{photons} \cdot \mathrm{m}^{-2} \cdot \mathrm{s}^{-1}\right]^{-1}\right)$ & $0.0323 \pm 0.0140$ & $0.0368 \pm 0.00680$ & $0.0302 \pm 0.00745$ & $0.0370 \pm 0.00846$ \\
$p_{\text {gmax } \text { Ulva }\left(\mathrm{mg} \mathrm{O}_{2} / \mathrm{h}\right)}$ & $0.477 \pm 0.0285$ & $0.420 \pm 0.0297$ & $0.375 \pm 0.0256$ & $0.396 \pm 0.0223$ \\
$p_{\text {gmax }}$ Ulvaria $\left(\mathrm{mg} \mathrm{O}_{2} / \mathrm{h}\right)$ & $0.337 \pm 0.0472$ & $0.381 \pm 0.0196$ & $0.329 \pm 0.0265$ & $0.313 \pm 0.0212$ \\
\hline
\end{tabular}

Notes: Collection and field sites were located within the San Juan Island Archipelago, Washington State, USA. Abbreviations are as follows: $p_{\text {nmax }}$ is the net light-saturated rate of photosynthesis, $p_{\text {gmax }}$ is the gross light-saturated rate of photosynthesis, and $\beta$ is a derived parameter that is proportional to the slope of the curve at low light intensities.

Table B2.9), as is consistent with acclimation to low light. There were no significant differences between species $(P=0.171)$, as might be expected if either were particularly well adapted to high- or low-light conditions.

\section{Salinity}

Growth of Ulvaria was reduced more by low salinity than that of Ulva, as predicted in hypothesis 3 (Fig. 3 and Appendix B, section 3). There was no interspecific difference at 20 and $30 \mathrm{PSU}$, with thalli growing $11 \%$ and $22 \%$, respectively, over the course of the experiment $(P=0.987$ and 0.965 , respectively). At 5 or 10 PSU, however, Ulva grew an average of $16 \%$ while Ulvaria lost tissue, decreasing in size $38 \%(P=0.004$ at 5 PSU and 0.009 at 10 PSU). Ulvaria grew significantly faster at 30 PSU than at 5 or 10 PSU $(P=0.002$ for both comparisons), but Ulva did not grow significantly faster at higher salinities than at lower salinities $(P>0.05)$.

\section{Nitrogen}

Variation in nitrogen physiology might explain differences in vertical distribution (hypothesis 4). In field measurements, $\mathrm{N}$ concentrations varied significantly between species $(P=0.004)$ and sites $(P<0.001)$, with Ulvaria having $13 \%$ more tissue $\mathrm{N}$ than Ulva $(4.94 \% \mathrm{dm}$ vs. $4.38 \% \mathrm{dm}$ ) and specimens from Armitage Bay, the site with higher seawater $\mathrm{N}$ concentrations, having tissue $\mathrm{N}$ concentrations $21 \%$ more than that of samples from

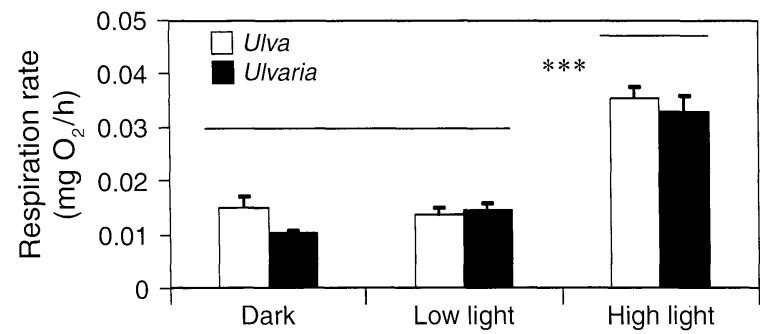

FIG. 2. Respiration rates (mean + SE) of algae acclimated to different light intensities. Lines indicate no significant difference between acclimation environments

$* * * P<0.001$.
West Beach (5.10\% vs. $4.23 \%$; Appendix B, Table B4.1 and Appendix D)

In the initial laboratory $\mathrm{N}$ addition experiment, we measured tissue nutrient and growth responses to nitrogen enrichment. When grown under identical conditions, Ulvaria had $47 \%$ more tissue $\mathrm{N}$ and $18 \%$ more tissue $\mathrm{C}$ than Ulva, but $21 \%$ lower $\mathrm{C}: \mathrm{N}$ and $15 \%$ slower growth rates (Fig. 4 and Appendix B, Tables B4.2 and B4.3; $P<0.001$ for all except growth, where $P=$ 0.016). Higher $\mathrm{N}$ treatments resulted in $19 \%$ and $70 \%$ higher tissue $\mathrm{N}$ concentration in the moderate- and highnitrogen treatments relative to the low-nitrogen treatment ( $P<0.05$ for all pairwise comparisons). Growth rates were $26 \%$ higher in the high-nitrogen treatment relative to the lowest nitrogen treatment $(P<0.05)$, with the moderate treatment having intermediate values that did not differ significantly from the high- or lownitrogen treatments $(P \geq 0.135$; Appendix B, Table B4.4).

The second laboratory manipulation examined effects of species and increased $\mathrm{N}$ on protein and chlorophyll, thus simultaneously examining nitrogen (hypothesis 4) and photosynthetic physiology (hypothesis 2). Ulvaria had 3.2 times as much protein $(12.2 \%$ vs. $2.66 \% \mathrm{dm}), 3.1$ times as much chl $a$ (217 vs. $47 \mu \mathrm{g} / \mathrm{g}$ fresh mass), and 4.4

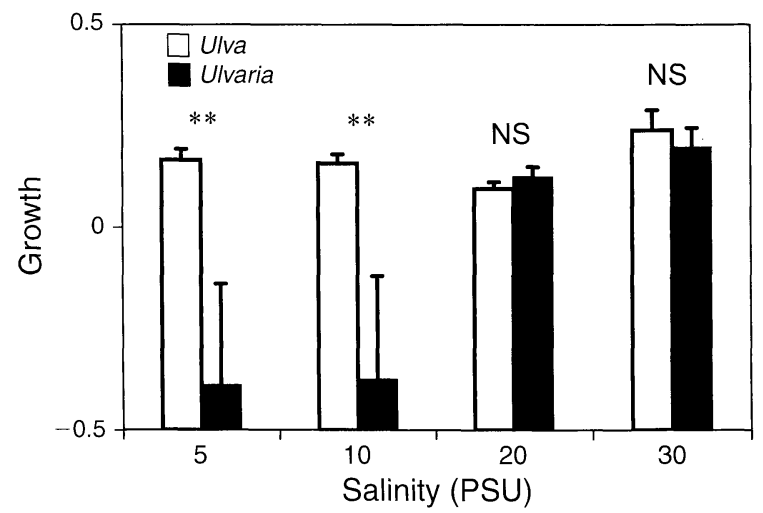

Fig. 3. Proportional growth (mean + SE) of Ulva and Ulvaria at different salinities. Growth of Ulva did not differ significantly among salinity treatments.

** $P<0.01$. NS, no significant difference between species. 

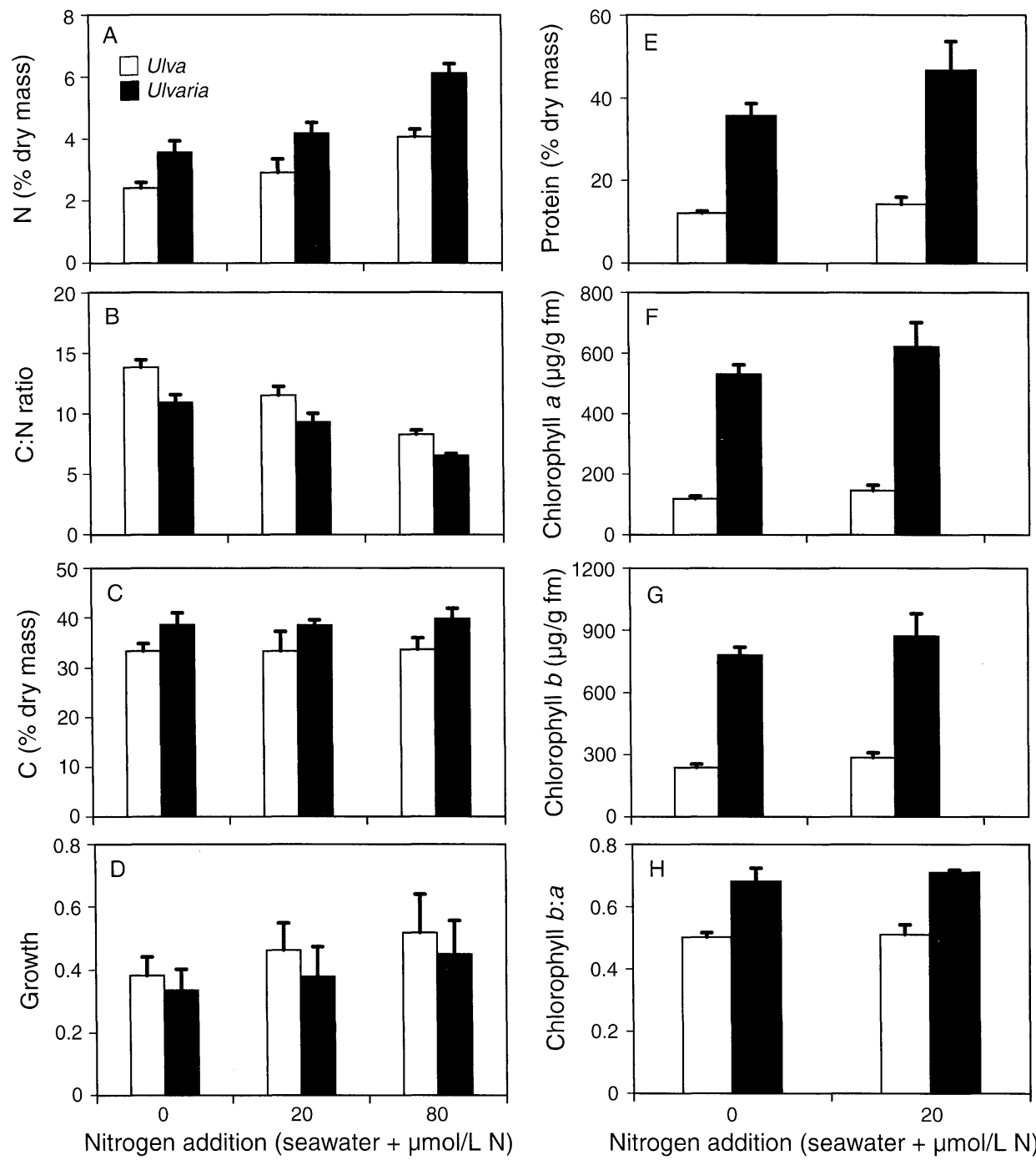

Nitrogen addition (seawater $+\mu \mathrm{mol} / \mathrm{L} \mathrm{N}$ )

FIG. 4. Proportional growth rate and tissue composition (mean $+\mathrm{SE} ; \mathrm{fm}=$ fresh mass) of algal thalli grown at different nutrient concentrations.

times as much chl $b$ (132 vs. $30 \mu \mathrm{g} / \mathrm{g}$ fresh mass) as Ulva (Fig. 4 and Appendix B, Table B4.5; $P<0.001$ for all comparisons). Ulvaria also had a chl $b: a$ ratio that was $38 \%$ higher than that of Ulva $(0.70$ vs. $0.51, P<0.001)$. The nutrient treatments had no significant effects on [protein], [chl $a$ or $b$ ], or chl $b: a(P=0.084,0.076,0.063$, and 0.361, respectively; Appendix B, Table B4.5). There was a trend, however, toward increased [chl] and [protein] in thalli grown at higher $\mathrm{N}$ concentrations.

\section{Grazing}

We expected Ulvaria to be more grazer resistant than Ulva (hypothesis 5). All tested grazers consumed significantly more Ulva than Ulvaria when presented with a choice (Fig. 5 and Appendix B, Table B5.1; see also Plate 1). In all cases no significant changes in thallus size were observed in controls lacking grazers $(P>$ 0.05 ). The three snails tested (L. sitkana, L. variegata, and $L$. vincta) ate small to moderate quantities of Ulva while generally ignoring Ulvaria. Ulva exposed to these three grazers lost $42 \%, 40 \%$, and $40 \%$ of its surface area, respectively. Ulvaria exposed to $L$. sitkana and $L$. variegata actually increased in size by $3.5 \%$ and $4.0 \%$, respectively, and Ulvaria exposed to L. vincta only lost $1.7 \%$ of its surface area. The difference was significant for all three grazers $(P<0.001$ for all comparisons). The urchins caused a $73 \%$ loss of Ulva, while only reducing the surface area of Ulvaria $6.8 \%(P<0.001)$. The isopods caused a $77 \%$ loss of the surface area in Ulva and an $18 \%$ loss in Ulvaria $(P=0.001)$. When $L$. vincta was not given a choice, the snails' consumption of Ulva and Ulvaria was not significantly different $(27 \%$ for Ulvaria vs. $23 \%$ for Ulva, $P=0.679$; Fig. 5). Conditioning led to a significant preference for the species that the snails had recently experienced $(P=$ 0.011 ). Snails acclimated to only Ulva caused a $35 \%$ 

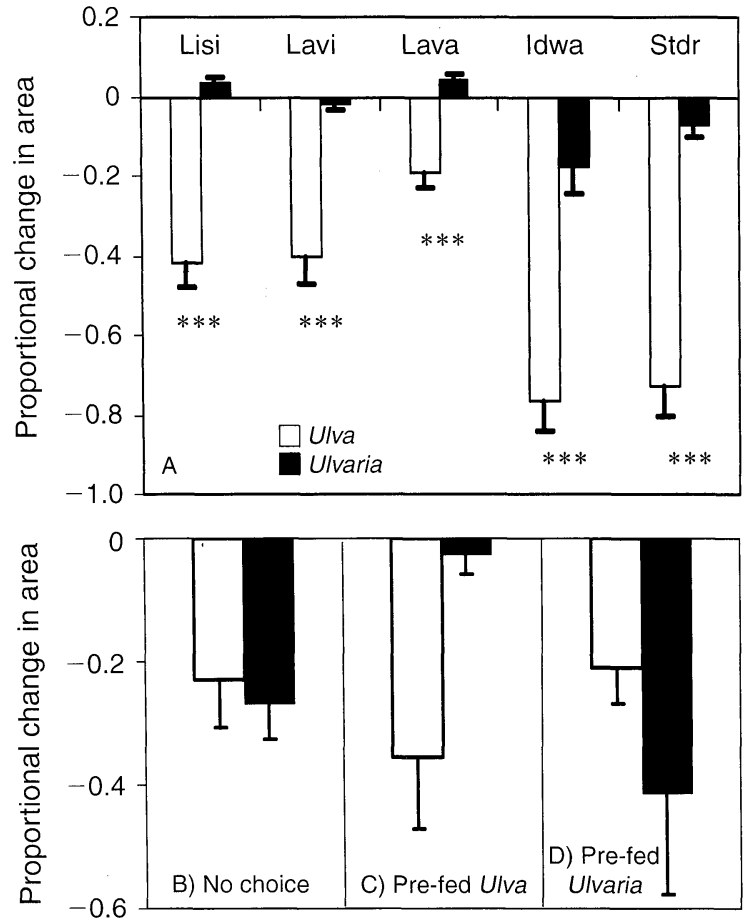

Fig. 5. Loss of tissue to grazing in grazing experiments (mean and SE): (A) results of choice experiments; (B, C, and D) results of no-choice and preconditioned grazing. Grazer abbreviations: Lisi, Littorina sitkana; Lavi, Lacuna vincta; Lava, Lacuna variegata; Idwa, Idotea wosnesenskii; Stdr, Strongylocentrotus droebachiensis. $* * * P \leq 0.001$

decrease in Ulva surface area but only a $2.5 \%$ decrease in Ulvaria surface area. Snails previously fed Ulvaria caused a $41 \%$ reduction in Ulvaria vs. a $21 \%$ reduction in Ulva (Fig. 5).

\section{Beach and tide pool comparison}

Ulvaria performed significantly better than Ulva when both were grown in tide pools (Fig. 6 and Appendix B, Table B5.2). In the Pinnacle Rock tide pool, Ulvaria thalli grew $14 \%$ more than Ulva $(P=0.024)$. At Cattle Point, tide-pool-grown Ulva lost $26.5 \%$ of its surface area, while Ulvaria gained $10 \%(P=0.038)$. In the exposed rocky intertidal zone, Ulva grew $23 \%$ while Ulvaria lost $23 \%$ of its thallus area $(P=0.031)$. In both tide pool and rocky intertidal situations, $100 \%$ of Ulva specimens appeared to have grazer damage. Grazer damage on Ulvaria was rare or nonexistent in all cases. Ulvaria specimens grown in the rocky intertidal zone did commonly have necrotic regions as typically seen at tissue death in this species.

\section{DisCUSSION}

Wohl et al. (2004: 1534) describe functionally redundant species as those that are "biologically unique" but contribute "with similar intensity to the same process within an ecosystem, such as energy flow or nutrient cycling." Ulvoid algal species are often thought of as functionally redundant, but differences between Ulva and Ulvaria in growth rates, photosynthesis, osmotic tolerance, nitrogen physiology, and grazer resistance suggest that they are not truly equivalent. Whether or not it is appropriate to refer to these species as functionally redundant, it seems apparent that the differences noted here would have significant impacts on community structure and function.

\section{Abiotic factors}

Studies of green macroalgal blooms have typically focused on physical or chemical factors that cause increased biomass. Differential performance among green algal species in response to salinity, nutrients, and light also play important roles in determining green tide species composition.

Ulvaria is relatively euhaline compared to locally abundant Ulva spp. (e.g., U. intestinalis and U. lactuca; Cohen and Fong 2004), so its absence from areas that are heavily influenced by freshwater input is expected. Ulvaria is usually found subtidally or in tide pools, where it is less likely to be affected by rainfall than the intertidal Ulva, and is absent or less common in the lower-salinity portions of estuaries in Washington State (Nelson et al. 2003b).

Both ulvoid algae in the area under study are likely nitrogen limited in late summer. While we found relatively high tissue nitrogen concentrations in specimens collected from the field in early summer, specimens collected in early September for laboratory studies had tissue nitrogen concentrations between $2 \%$ and $3 \%$, suggesting nitrogen limitation (Björnsätter and Wheeler 1990, Pedersen and Borum 1996). Further, supplemental nitrogen increased growth rates in our study.

Species-specific differences in growth rate and critical $\mathrm{N}$ concentrations are important in determining the degree and extent of $\mathrm{N}$ limitation (Pedersen and Borum 1996). Whether or not the additional $\mathrm{N}$ in Ulvaria allows it to continue growth during periods of low seawater $\mathrm{N}$

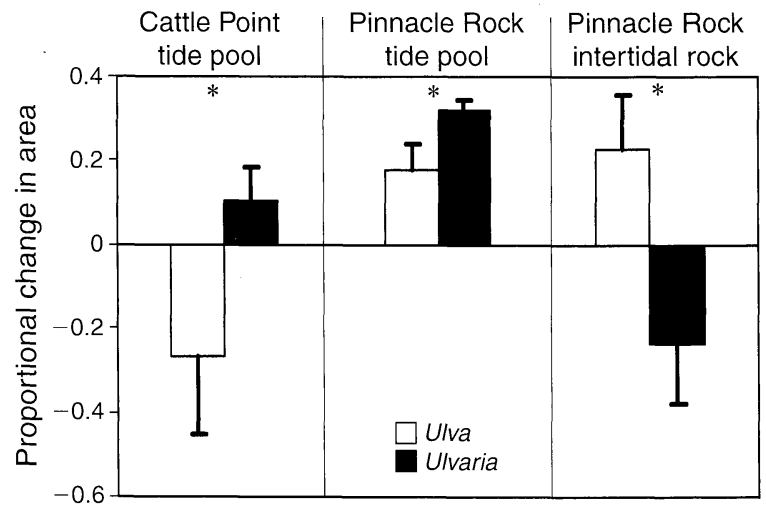

FIG. 6. Results (mean and SE) of field grazing experiments in pools and on exposed rocks.

$* P<0.05$. 

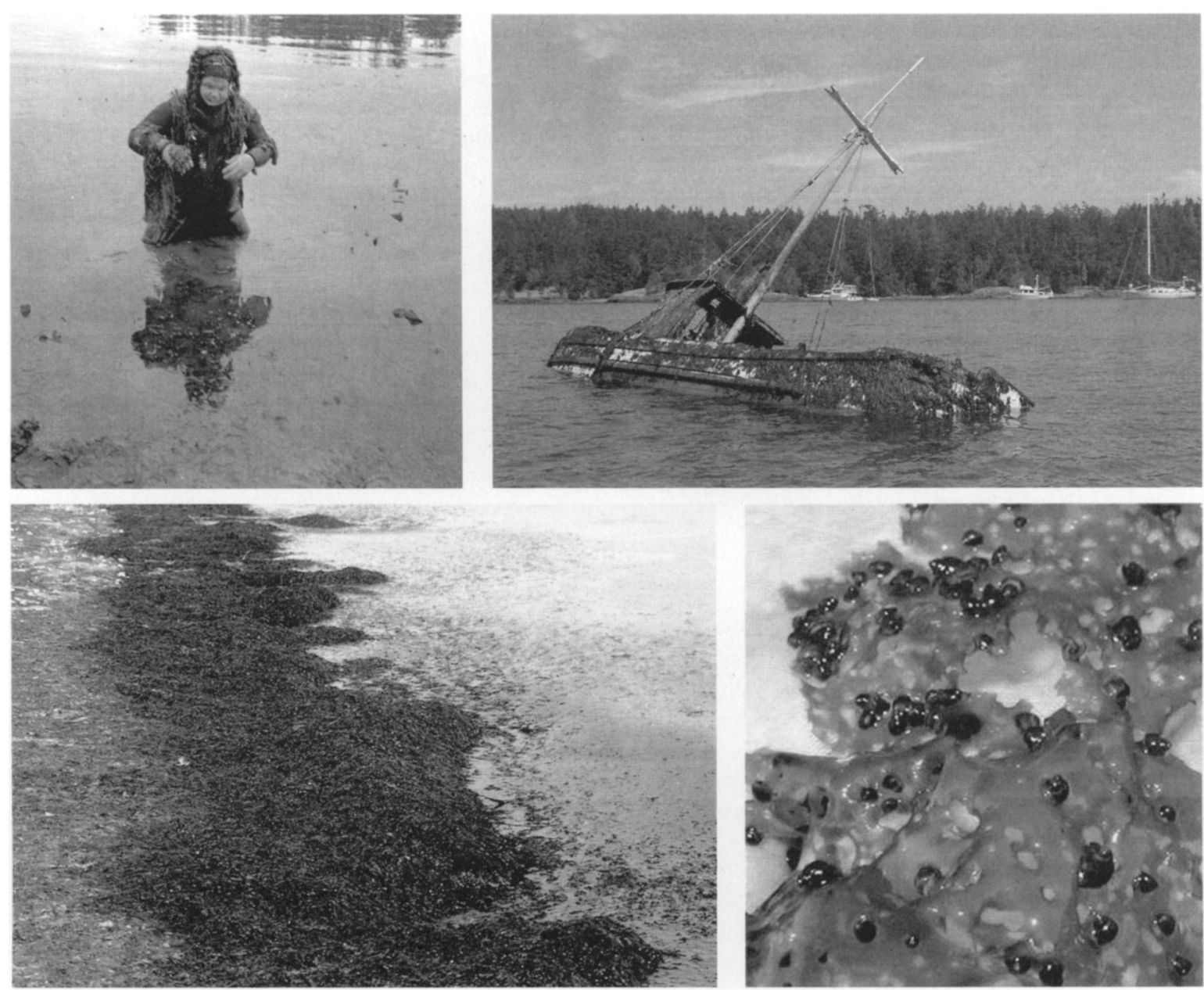

PLATE 1. (Upper left) Ulvoid algal bloom sufficient to inhibit eelgrass growth in Armitage Bay, Blakely Island, Washington, USA (photo credit: A. V. Nelson). (Upper right) Derelict vessel in Parks Bay, Shaw Island, Washington State, USA, with ulvoid algae covering the hull (photo credit: T. A. Nelson). Green algal blooms have not yet been reported to be a threat to navigation (Lower left) Ulvoid algae (Ulva sp.) form mats $\sim 0.5 \mathrm{~m}$ thick on Sidney Spit, Sidney Island, British Columbia, Canada (photo credit: T. A. Nelson). (Lower right) Ulva sp. covered with abundant Lacuna vincta. The algal thallus shows substantial grazing damage (photo credit: K. L. Van Alstyne).

concentration may also hinge on whether its higher tissue $\mathrm{N}$ is constitutive or may be consumed to supply growth. Higher tissue $\mathrm{N}$ concentration is likely constitutive since Ulvaria produces dopamine and more chlorophyll and protein than Ulva when grown under identical conditions.

These interspecific differences in $\mathrm{N}$ physiology could affect management decisions related to the control of blooms. For example, Ulvaria stores more $\mathrm{N}$ per unit biomass than Ulva; thus, for a given quantity of excess $\mathrm{N}$, there will be less Ulvaria than Ulva. Since respiration rates are similar in these species, Ulvaria may be a better buffer against eutrophication-induced anoxia than Ulva.

Ulva acclimates to the light environment in which it is grown, while Ulvaria appears to lack this plasticity and performs consistently as though grown under low-light conditions. Acclimation to low light is obviously advantageous in the relatively dark environment of the subtidal zone and may also be effective in blooms, where self-shading is common (Brush and Nixon 2003) or when algae are shaded by neighboring organisms. For Ulvaria, a bloom-forming alga restricted to the subtidal zone or tide pools by physical factors, selective pressures for acclimation to high light intensity may be trivial or nonexistent.

\section{Biotic factors}

Beyond these physical factors, interspecific interactions may also determine species composition in green algal blooms. The ability of Ulvaria to dominate the subtidal zone appears partly to be an indirect effect of grazers' preference for Ulva. Ordinarily, grazers prefer and eat more of a producer that has high tissue $\mathrm{N}$ and protein content (Cebrian and Lartigue 2004), and snails have been shown to eat more Ulva lactuca when tissue $\mathrm{N}$ content is high (Giannotti and McGlathery 2001). Given 
the higher tissue $\mathrm{N}$ and protein content in Ulvaria relative to Ulva, the preference for Ulva is surprising. However, Ulvaria appears to be chemically defended.

Ulvaria produces dopamine (Tocher and Craigie 1966), which has recently been shown to deter grazing by Strongylocentrotus droebachiensis, Idotea wosnesenskii, and Littorina sitkana (Van Alstyne et al. 2006). Among chemical defenses, phenolic compounds and alkaloids tend to have a greater negative fitness trade-off to the producer than do terpenoids (Koricheva 2002). Dopamine is a phenolic compound and, like alkaloids, includes N. Either the use of a limited resource $(\mathrm{N})$ in the production of dopamine or costs associated with its toxic impacts on the alga (Nelson et al. 2003a) could lead to the lower growth rates seen in this alga.

Interestingly, the snail L. vincta eats as much Ulvaria as Ulva in no-choice experiments, despite preferring Ulva when presented with a choice. Once acclimated to Ulvaria, the snails prefer it over Ulva. Padilla (1998) found that Lacuna produces different tooth morphologies to match their food source (diatoms vs. kelp, in that study). Perhaps Lacuna is adjusting digestive physiology in a similar manner. Alternatively, since radular teeth acclimate to food source and tooth replacement is not instantaneous, it may be generally advantageous for this snail to feed on algae that "taste" similar to their usual food even if there is no specific selective advantage in the case of ulvoid algae.

Past studies of grazing on Ulvaria and Ulva have yielded conflicting results. Lemire and Himmelman (1996) tested a variety of algal diets on growth and fitness of urchins and found that Ulvaria was intermediate in effect, comparable to chemically defended Fucus gardneri, but preferred to the more heavily defended Agarum. Price and Hylleberg (1982) found that gammaridean amphipods ate more Ulvaria than Ulva in a no-choice field experiment. They concluded, based on the assumption that large quantities of Ulvaria were being lost to consumption, that Ulvaria was substantially more productive than Ulva. This is in marked contrast to our observation that every tested grazer preferred Ulva to Ulvaria and that Ulva grows faster than Ulvaria. Amphipods may be unusual among marine grazers, preferring to live on and eat chemically defended seaweeds (Hay et al. 1987). Alternatively, since grazing was examined in a no-choice experiment, Price and Hylleberg's result may have illustrated a compensatory feeding response.

\section{Synthesis}

We conclude that Ulva dominates the intertidal zone primarily because it is more tolerant of abiotic factors, acclimating more readily to high light intensity, and generally grows faster than Ulvaria. In the subtidal zone, the two species appear to be equivalent competitors for light and have similar growth rates, but herbivore deterrents in Ulvaria protect it from grazers.
Our data support a general concept of physical processes (i.e., bottom-up) controlling species composition on the higher reaches of the shoreline, while biotic factors (i.e., top-down) control species composition lower on the shore, as seen by, e.g., Connell (1961) in barnacles. In Washington State, Mazzaella parksii's (Rhodophyta) range is controlled by physiological factors at its upper limit and by grazing at its lower limit (Harley 2003). In salt marsh settings, the reverse situation has been seen. Lower marsh plant species composition is controlled by physical stress, but higher in the marsh competition predominates (Bertness 1991). However, salt marsh communities consist of species evolved from freshwater angiosperms, while barnacles and ulvoid algae are evolved from marine ancestors. Thus, physical factors still control species composition in the evolutionarily novel habitat, while biotic factors control species distribution in the original environment.

Given the similarity in structure between Ulva and Ulvaria, one might expect only one of the species to survive during a bloom, yet both are often seen in the same site and occasionally at the same tidal elevation. Ulvaria can be found in heavily grazed intertidal pools, where it is sometimes the last surviving frondose alga Despite the observation that Ulvaria dominates the subtidal zone at most sites, Ulva alone is found subtidally in some sites (Nelson et al. 2003b). This could be due to spatial or temporal refuges from grazers or other environmental factors (e.g., low salinity) that provide Ulva with an advantage even in the presence of heavy grazing.

Whether herbivores constrain or excessive nutrients cause macroalgal blooms has been debated. In temperate ulvoid blooms, excess nitrogen is often regarded as the causal agent (Valiela et al. 1997). In contrast, macroalgal blooms in some coral reef systems are controlled by herbivores (e.g., Miller et al. 1999). In Oregon tide pools, both grazers and nutrients affect algal biomass (Nielsen 2001). The present study and our past work (Nelson et al. 2003b) suggest that species composition in temperate ulvoid blooms may be controlled by herbivory, but that elevated nitrogen would generally lead to increased ulvoid biomass.

Coley et al. (1985) predict that plants growing in resource-poor environments will grow more slowly, have lower maximal photosynthetic rates, have lower protein concentrations in their leaves, and produce larger quantities of defensive chemicals from a nonlimiting nutrient. Ulvaria appears to display a mix of these traits relative to Ulva. Ulvaria does have lower growth and photosynthetic rates and is chemically defended. However, it also has higher tissue [protein] and, though likely $\mathrm{N}$-limited, produces a $\mathrm{N}$-containing defensive compound (Van Alstyne et al. 2006). This may be consistent with the environments in which Ulvaria thrives, i.e., the subtidal zone and heavily grazed tide pools. In the former, light may be more limiting than $\mathrm{N}$ for much of 
the year. In the latter, excretion by grazers may supply sufficient N (Bracken and Nielsen 2004).

It is an open question as to whether our field grazing results from rocky intertidal areas can be applied to the softer substratum environments in which green macroalgal blooms often occur. The general pattern of Ulvaria occupying the lower intertidal zone and subtidal zone and Ulva dominating the higher intertidal zone holds for both rocky and soft substrata (Nelson et al. 2003b). If the hypotheses suggested by our other field experiments accurately describe controls of species composition, they should hold in the rocky as well as in the soft-sediment environments. However, the applicability of the rocky intertidal grazing experiments to soft-substratum systems should be considered with caution.

\section{ACKNOWLEDGMENTS}

R. Prins, E. Posthumus, K. Hammer, K. LaFleur, R. Render, J. Rathbun, and M. Tjoelker provided assistance in the field and laboratory. B. Congdon and A. O. D. Willows provided facilities at Blakely Island Field Station and Friday Harbor Laboratories, respectively. The manuscript was improved based on comments of E. Long and two anonymous reviewers. This work was funded by grants from the Murdock College Research Program for Life Sciences and the National Science Foundation (NSF OCE 0525385) to T. A. Nelson, NSF grants (DBI-0098409 and IOB-0090825) to K. L. Van Alstyne, and a grant from the National Oceanic and Atmospheric Administration (NA05NOS4781192) to K. L. Van Alstyne and T. A. Nelson. This paper is number 242 from the Ecology and Oceanography of Harmful Algal Blooms program.

\section{Literature Cited}

Aitken, A., and M. Learmonth. 1996. Protein determination by UV absorption. Pages 3-6 in J. M. Walker, editor. The protein protocols handbook. Humana Press, Totowa, New Jersey, USA.

Anderson, R. J., P. M. S. Monteiro, and G. J. Levitt. 1996. The effect of localised eutrophication on competition between Ulva lactuca (Ulvaceae, Chlorophyta) and a commercial resource of Gracilaria verrucosa (Gracilariaceae, Rhodophyta). Hydrobiologia 326/327:291-296.

Bertness, M. D. 1991. Interspecific interactions among high marsh perennials in a New England salt marsh. Ecology 72 : 125-137.

Björnsätter, B. R., and P. A. Wheeler. 1990. Effect of nitrogen and phosphorus supply on growth and tissue composition of Ulva fenestrata and Enteromorpha intestinalis (Ulvales, Chlorophyta). Journal of Phycology 26:603-611.

Bracken, M. E. S., and K. J. Nielsen. 2004. Diversity of intertidal macroalgae increases with nitrogen loading by invertebrates. Ecology 85:2828-2836.

Brush, S. J., and S. W. Nixon. 2003. Biomass layering and metabolism in mats of the macroalga Ulva lactuca L. Estuaries 26:916-926.

Cebrian, J., and J. Lartigue. 2004. Patterns of herbivory and decomposition in aquatic and terrestrial ecosystems. Ecological Monographs 74:237-259.

Cohen, R. A., and P. Fong. 2004. Physiological responses of a bloom-forming green macroalga to short-term changes in salinity, nutrients, and light help explain its ecological success. Estuaries 27:209-216.

Coley, P. D., J. P. Bryant, and F. S. Chapin, III. 1985. Resource availability and plant antiherbivore defense. Science 230:895899.
Connell, J. H. 1961. The influence of interspecific competition and other factors on the distribution of the barnacle Chthamalus stellatus. Ecology 42:710-723.

Coutinho, R., and R. Zingmark. 1993. Interactions of light and nitrogen on photosynthesis and growth of the marine macroalga Ulva curvata (Kützing) De Toni. Journal of Experimental Marine Biology and Ecology 167:11-19.

Cronin, G., and M. E. Hay. 1996. Effects of light and nutrient availability on the growth, secondary chemistry, and resistance to herbivory of two brown seaweeds. Oikos 77 93-106

Fong, P., K. E. Boyer, J. S. Desmond, and J. B. Zedler. 1996 Salinity stress, nitrogen competition, and facilitation: What controls seasonal succession of two opportunistic green macroalgae? Journal of Experimental Marine Biology and Ecology 206:203-221.

Geertz-Hansen, O., K. Sand-Jensen, D. F. Hansen, and A. Christiansen. 1993. Growth and grazing control of the marine macroalga, Ulva lactuca L. in a eutrophic Danish estuary. Aquatic Botany 46:101-109.

Giannotti, A. L., and K. J. McGlathery. 2001. Consumption of Ulva lactuca (Chlorophyta) by the omnivorous mud snail Ilyanassa obsoleta (Say). Journal of Phycology 37:209-215.

Harley, C. D. G. 2003. Abiotic stress and herbivory interact to set range limits across a two-dimensional stress gradient. Ecology 84:1477-1488.

Hay, M. E., J. E. Duffy, C. A. Pfister, and W. Fenical. 1987. Chemical defense against different marine herbivores: Are amphipods insect equivalents? Ecology 68:1567-1580.

Henley, W. J., G. Levavasseur, L. A. Franklin, C. B. Osmond, and J. Ramus. 1991. Photoacclimation and photoinhibition in Ulva rotundata as influenced by nitrogen availability. Planta 184:235-243.

Henley, W. J., and J. Ramus. 1989. Optimization of pigment content and the limits of photoacclimation for Ulva rotundata (Chlorophyta). Marine Biology 103:267-274.

Josselyn, M. 1985. Do nutrients or physical factors control macroalgal growth in temperate estuaries? Estuaries 8:30A.

Kida, W. 1990. Culture of the seaweed Monostroma. Marine Behaviour and Physiology 16:109-131.

Koricheva, J. 2002. The carbon-nutrient balance hypothesis is dead; Long live the carbon-nutrient balance hypothesis? Oikos 98:537-539.

Lemire, M., and J. H. Himmelman. 1996. Relation of food preference to fitness for the green sea urchin, Strongylocentrotus droebachiensis. Marine Biology 127:73-78.

Littler, M. M., and D. S. Littler. 1980. The evolution of thallus form and survival strategies in benthic marine macroalgae: field and laboratory tests of a functional form model. American Naturalist 116:25-44.

Lobban, C. S., D. J. Chapman, and B. P. Kremer. 1988. Experimental phycology: a laboratory manual. Cambridge University Press, Cambridge, UK

Lobban, C. S., and P. J. Harrison. 1994. Seaweed ecology and physiology. Cambridge University Press, Cambridge, UK.

Lotze, H. K., and W. Schramm. 2000. Ecophysiological traits explain species dominance patterns in macroalgal blooms. Journal of Phycology 36:287-295.

Lotze, H. K., W. Schramm, D. Schories, and B. Worm. 1999. Control of macroalgal blooms at early developmental stages: Pilayella littoralis versus Enteromorpha spp. Oecologia 119: 46-54.

Lotze, H. K., B. Worm, and U. Sommer. 2000. Propagule banks, herbivory and nutrient supply control population development and dominance patterns in macroalgal blooms. Oikos 89:46-58.

Miller, M. W., M. E. Hay, S. L. Miller, D. Malone, E. E. Sotka, and A. M. Szmant. 1999. Effects of nutrients versus herbivores on reef algae: a new method for manipulating nutrients on coral reefs. Limnology and Oceanography 44: 1847-1861. 
Nelson, T. A., and A. Lee. 2001. A manipulative experiment demonstrates that ulvoid algal blooms reduce eelgrass shoot density. Aquatic Botany 71:149-154.

Nelson, T. A., D. J. Lee, and B. C. Smith. 2003a. Toxic extracts from ulvoid macroalgae: Are "green tides" harmful algal blooms? Journal of Phycology 39:874-879.

Nelson, T. A., A. V. Nelson, and M. Tjoelker. 2003b. Seasonal patterns in ulvoid algal biomass, productivity, and key environmental factors in the Northeast Pacific. Botanica Marina 46:263-275.

Nelson, T. A., and J. R. Waaland. 1997. Seasonality of eelgrass, epiphyte, and grazer biomass and productivity in subtida eelgrass meadows subjected to moderate tidal amplitude Aquatic Botany 56:51-74

Nielsen, K. J. 2001. Bottom-up and top-down forces in tide pools: test of a food chain model in an intertidal community. Ecological Monographs 71:187-217.

Padilla, D. K. 1998. Inducible phenotypic plasticity of the radula in Lacuna. Veliger 41:201-204.

Pedersen, M. F., and J. Borum. 1996. Nutrient control of algal growth in estuarine waters: nutrient limitation and the importance of nitrogen requirements and nitrogen storage among phytoplankton and species of macroalgae. Marine Ecology Progress Series 142:261-272.

Peterson, D. H., M. J. Perry, K. E. Bencala, and M. C. Talbot. 1987. Phytoplankton productivity in relation to light intensity: a simple equation. Estuarine, Coastal, and Shelf Science 24:813-832.

Phillips, J. C., and C. L. Hurd. 2003. Nitrogen ecophysiology of intertidal seaweeds from New Zealand. Marine Ecology Progress Series 264:31-48.

Phillips, J. C., and C. L. Hurd. 2004. Kinetics of nitrate, ammonium, and urea uptake by four intertidal seaweeds from New Zealand. Journal of Phycology 40:534-545.

Price, L. H., and J. Hylleberg. 1982. Algal-faunal interactions in a mat of Ulva fenestrata in False Bay, Washington. Ophelia 21:75-88.

Ramus, J., S. I. Beale, D. Mauserall, and K. L. Howard. 1976. Changes in photosynthetic pigment concentration in seaweeds as a function of water depth. Marine Biology 37:223229 .
Rivers, J. S., and P. Peckol. 1995. Summer decline of Ulva lactuca (Chlorophyta) in a eutrophic embayment: interactive effects of temperature and nitrogen availability. Journal of Phycology 31:223-228.

Robles, C., and R. Desharnais. 2002. History and current development of a paradigm of predation in rocky intertidal communities. Ecology 83:1521-1536.

Sfriso, A., A. Marcomini, and B. Pavoni. 1987. Relationships between macroalgal biomass and nutrient concentrations in a hypertrophic area of the Venice Lagoon. Marine Environmental Research 22:297-312.

Steneck, R. S., and M. N. Dethier. 1994. A functional group approach to the structure of algal-dominated communities. Oikos 69:476-498.

Taylor, D., S. Nixon, S. Granger, and B. Buckley. 1995. Nutrient limitation and the eutrophication of coastal lagoons. Marine Ecology Progress Series 127:235-244.

Taylor, R., R. L. Fletcher, and J. A. Raven. 2001. Preliminary studies on the growth of selected 'green tide' algae in laboratory culture: effects of irradiance, temperature, salinity and nutrients on growth rate. Botanica Marina 44:327-336.

Tocher, R. D., and J. S. Craigie. 1966. Enzymes of marine algae. II. Isolation and identification of 3-hydroxytyramine as the phenolase substrate in Monostroma fuscum. Canadian Journal of Botany 44:605-608.

Valiela, I., J. McClelland, J. Hauxwell, P. J. Behr, D. Hersh, and K. Foreman. 1997. Macroalgal blooms in shallow estuaries: controls and ecophysiological and ecosystem consequences. Limnology and Oceanography 42:1105-1118.

Van Alstyne, K. L., L. Koellermeier, and T. A. Nelson. 2007. Spatial variation in dimethylsulfoniopropionate (DMSP) production in Ulva lactuca (Chlorophyta) from the Northeast Pacific. Marine Biology 150:1127-1135.

Van Alstyne, K. L., A. V. Nelson, J. R. Vyvyan, and D. A Cancilla. 2006. Dopamine functions as an antiherbivore defense in the temperate green alga Ulvaria obscura. Oecologia 148:304-311

Wohl, D. L., S. Arora, and J. R. Gladstone. 2004. Functional redundancy supports biodiversity and ecosystem function in a closed and constant environment. Ecology 85:1534-1540.

Zar, J. H. 1999. Biostatistical analyses. Prentice-Hall, Upper Saddle River, New Jersey, USA.

APPENDIX A

Detailed site descriptions and expanded methods (Ecological Archives E089-078-A1)

APPENDIX B

Statistical tables (Ecological Archives E089-078-A2).

APPENDIX C

Net photosyntheses vs. irradiance for Ulva and Ulvaria grown at various depths (Ecological Archives E089-078-A3).

APPENDIX D

Tissue nutrient content in algae collected from low- and high-nitrogen sites (Ecological Archives E089-078-A4). 